\title{
Ecological relationships between phytoplankton communities and different spatial scales in European reservoirs: implications at catchment level monitoring programmes
}

\author{
Edna Cabecinha - Paul J. Van den Brink • \\ João Alexandre Cabral · Rui Cortes · \\ Martinho Lourenço • Miguel Ângelo Pardal
}

Received: 7 May 2008/Revised: 1 February 2009/Accepted: 9 February 2009/Published online: 25 February 2009

(C) Springer Science+Business Media B.V. 2009

\begin{abstract}
Phytoplankton communities are structured by factors acting over temporal and spatial scales. Identifying which factors are driving spatial patterns in aquatic communities is the central aim of ecology. In this study, data sets of phytoplankton communities and environmental data of two Portuguese reservoirs types (lowland "riverine reservoirs" and higher altitude "artificial lake reservoirs") were used to determine the importance of environmental variables at different spatial (geographical, regional and local) and time scales (seasons, years) on the community structure. In all the data sets, the multivariate ordination technique
\end{abstract}

Handling editor: J. Padisak

Electronic supplementary material The online version of this article (doi:10.1007/s10750-009-9731-y) contains supplementary material, which is available to authorized users.

E. Cabecinha $(\varangle) \cdot$ J. A. Cabral

Laboratory of Applied Ecology, CITAB-Department of Biological and Environmental Engineering, University of Trás-os-Montes e Alto Douro, 5000-911 Vila Real,

Portugal

e-mail: edna@utad.pt

P. J. Van den Brink

Alterra, Wageningen University and Research Centre,

PO Box 47, 6700 AA Wageningen, The Netherlands

P. J. Van den Brink

Department of Aquatic Ecology and Water Quality

Management, Wageningen University and Research

Centre, P.O. Box 47, 6700 AA Wageningen,

The Netherlands
Canonical Correspondence Analysis (CCA) showed that regional and local scales explained the majority (9-18\% and 13-19\%, respectively) of the taxa variance. However, for "riverine reservoirs", time variables were more important, explaining $27 \%$ of the variability in phytoplankton assemblages. Variance partitioning was used to assess the individual importance of the three spatial scales and time for the community structure of the two reservoir types. The majority of among-site variability (5.9-21.4\%) was accounted for by time variables, with local, regional, and geographical scale variables accounting for 3.3$5.6 \%, 3.7-4.5 \%$ and $2.6-2.9 \%$, respectively. The effects of different spatial scales on phytoplankton communities were clearly interrelated; thus, implying that phytoplankton assemblages are capable of detecting stress from catchment to site scales.

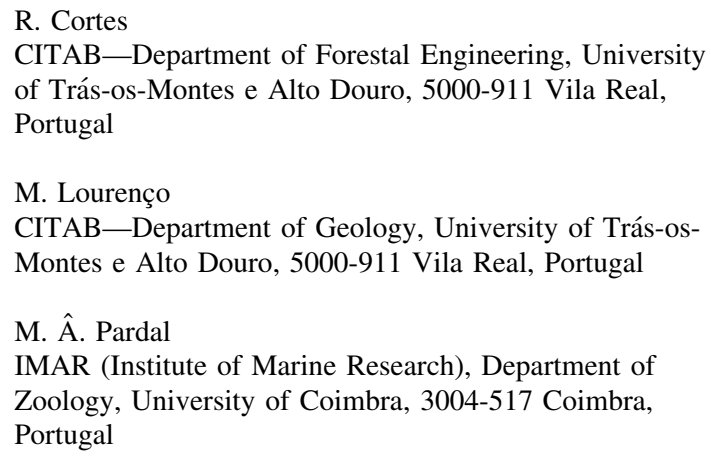


Keywords Phytoplankton - Ecological status ·

Reservoirs - Spatial scales - Multivariate analysis . Partial constrained ordination

\section{Introduction}

The quality and availability of freshwater is one of the most essential determinants for the health of ecosystems and human societies worldwide. Human activities have exploited this resource heavily, and consequently severely deteriorated freshwater ecosystems. Hydrological changes, physical disturbances, point and non-point sources of pollution, from both rural and urban activities, are all examples of processes responsible for the large-scale deterioration of freshwater systems and lentic waters, such as, for instance, reservoirs (Dziock et al., 2006; Brazner et al., 2007; Danz et al., 2007). Reservoirs are artificial lentic water bodies, generally, associated with multiple objectives for human benefits such as water supply, irrigation, hydroelectric power and recreation. Land-use changes in the watershed, overlapping in space and time, may have considerable effects on the reservoirs, and may lead to the disruption of the structure and functioning of these man-made systems (Reynolds \& Petersen, 2000; Vasconcelos, 2001). For effective conservation strategies, large-scale management, incorporating the importance of ecosystem scale and connectivity, is essential. Not surprisingly, integrating pattern and scale is a central theme in ecology and a topic that has received considerable attention during the last few years (Dziock et al., 2006; Brazner et al., 2007; Danz et al., 2007). Indeed, recognition of which factor(s) structure reservoir and lake ecosystems has evolved from single to multiple variables and from control at the habitat scale to involving factors at the global scale (Li et al., 2001). Much interest in the importance of scale-related factors for community composition has been derived from the need to better understand how organism groups or assemblages are linked with their immediate habitat and the surrounding landscape.

This information is also of interest to managers aiming to design more robust monitoring programmes. For example, although not always clearly stated, the idea that organisms respond differently at different levels of spatial scale is often embedded in many monitoring designs. Fish communities are often considered to be responsive to large scale (e.g. catchment level) alterations in land use and cover, while benthic invertebrate and diatom communities are thought to respond to more local alterations in habitat quality (Johnson et al., 2007). Knowledge of scale-related responses, if present, could be used to design more robust monitoring programmes. In Europe, as worldwide, there is a long history of using biological indicators to monitor the integrity of lentic ecosystems (e.g. Moss et al., 2003). Building on this long tradition of using organisms in monitoring and assessment programmes, the European Commission issued a directive mandating the use of different organism groups to monitor the integrity of inland waters and coastal regions (European Commission, 2000). The Water Framework Directive requires the use of different organism groups such as fish, invertebrates, macrophytes and benthic diatoms, either singly or together, in assessing the ecological status of reservoirs ecosystems.

In this article, the phytoplankton communities were used as ecological indicator, since they represent the basis of lake and reservoir food webs and respond fast to stresses and perturbations (Çelik \& Ongun, 2007). Therefore, in this study, we investigated how phytoplankton communities from two different types of Portuguese reservoirs, located in the North and Centre of Portugal, respond to different spatial factors and time. For this, we used a relatively large data set, where phytoplankton was sampled using the standardized methodology, over a long period of time (9 years) and across a gradient of land cover types in which agriculture was the predominant stressor. Using this data set, it was analysed how the variability in species composition of reservoir's phytoplankton communities was related to geographical, regional and local scale environmental factors. The objective was to assess the importance of environmental variables at different spatial (geographical, regional and local) and time scales (seasons, years) in structuring reservoirs communities and consequently determined if phytoplankton response would be related differently to large-scale, regional variability or local factors. With this information, the predictions of how human alterations affect lentic water ecosystems and herewith the planning and implementation of conservation and management programmes can be improved. 


\section{Materials and methods}

\section{Study area}

This study was carried out using data from 34 reservoirs in six catchments located in central and northern Portugal. The catchments were: Ave (1 reservoir), Cávado (6 reservoirs), Mondego (5 reservoirs), the Portuguese part of the international basins of Lima (2 reservoirs), Douro (11 reservoirs) and Tagus (9 reservoirs). The main purpose of all these reservoirs is to provide hydroelectric power, although some secondary uses, such as navigation, irrigation, water supply and recreation are also common. This extensive geographic area represents a wide range in physical and chemical characteristics, soil use and anthropogenic pressure, including both good and poor water quality conditions. A recent analysis of these data showed that phytoplankton community composition differed markedly between high altitude and lowland reservoirs (Cabecinha et al., 2009); hence, these two reservoir groups were analysed separately here. The two groups comprise: Type 1lowland "run-of-river" reservoirs located in the main rivers (Douro and Tagus), with a very short residence time ( $n=10)$; Type 2-deeper high altitude reservoirs, largely located in tributaries, with long residence time $(n=24)$ (Fig. 1). Lowland reservoirs ranged from $39^{\circ}$ to $41^{\circ} \mathrm{N}$ latitude and $6^{\circ}$ to $8^{\circ} \mathrm{W}$ longitude, while higher altitude reservoirs ranged from $39^{\circ}$ to $42^{\circ} \mathrm{N}$ latitude and from $7^{\circ}$ to $8^{\circ} \mathrm{W}$ longitude (Table 1). "Run-of-river reservoirs" were generally situated at lower altitudes, had larger catchments, lower residence time and were higher in mineral content (hardness and conductivity), than higher altitude reservoirs (Table 1). In addition, Type 1 reservoirs were more nutrient rich (total phosphate and nitrates) than Type 2. Catchment land use and cover were quite different between the two reservoirs groups. Type 2 reservoirs had, on average, a higher percentage of their catchments classified as natural areas than lowland reservoirs, whereas catchments of lowland reservoirs consisted more of extensive agriculture and intensive (Table 1).

Environmental parameters and chlorophyll $a$

From 1996 to 2004, the environmental and biological parameters were measured by the Laboratory of Environment and Applied Chemistry (LABELEC) four times per year, corresponding to spring (April/
May), summer (July/August), autumn (October/ November) and winter (January/February). The sampling periodicity was carried out on an annual base for $58 \%$ of the reservoirs. The remaining reservoirs were visited biannually (27\%) and triennially (15\%) (Cabecinha et al., 2009). All the samples were collected at $100 \mathrm{~m}$ from the reservoirs's crest, at two different depths: (a) near the surface (approximately $0.5 \mathrm{~m}$ depth); and (b) near the bottom ( $2 \mathrm{~m}$ above bottom, only for environmental parameters and chlorophyll $a$ ). Water samples were analysed following standard procedures (APHA, 1995).

The environmental data set (78 variables) was divided into four categories: spatial or geographical (G) (site coordinates; 9 variables), regional (R) (9 variables, e.g. catchment land use/cover), local (L) (26 variables, e.g. hydro-morphological) and time variables ( $\mathrm{T}$ ) (all sampling dates, i.e. interaction between sampling year and season) (see Table 2). The geographical coordinates of the sampling sites were expanded into third order polynomial terms to allow for non-linear responses (Legendre \& Legendre, 1998). Including such a spatial component in the analysis allows for capturing large-scale spatial structures in the data set (Meót et al., 1998). The constructed spatial component explains patterns in the species data that are not shared by any of the measured environmental data; this spatial pattern could be caused by some biological process or by environmental factors affecting the assemblage structure, but not explicitly measured in the study (Borcard et al., 1992). This also allows for testing of complex spatial trends in the data set (Økland \& Eilertsen, 1994). The spatial variables were calculated by including all the terms for a cubic trend surface regression (i.e. $x, y, x^{2}, x y, y^{2}, x^{3}, x^{2} y, x y^{2}$ and $y^{3}$ ), with $x$ (latitude) and $y$ (longitude) being the geographical co-ordinates of the sampling site (Borcard et al., 1992; Meót et al., 1998).

To determine the ecological status of the reservoirs' watersheds, a geographic information system database was created (ESRI, ArcGIS 9.0), with 12 spatial variables. These variables were classified into four categories of anthropogenic stress measures that are prominent in the study area:

(i) Land cover-six land use/land cover variables derived primarily from the Corine Land Cover (CLC, 1990 and 2000; Instituto Geográfico do Exército (Geografic Military Institute), 2006). 
Fig. 1 Location of the two Portuguese reservoirs types studied and their distribution through six catchments: Ave, Cávado, Mondego and the Portuguese part of the international basins of Lima, Douro and Tagus.

Triangles and circles represent reservoirs of Type 1 and Type 2, respectively

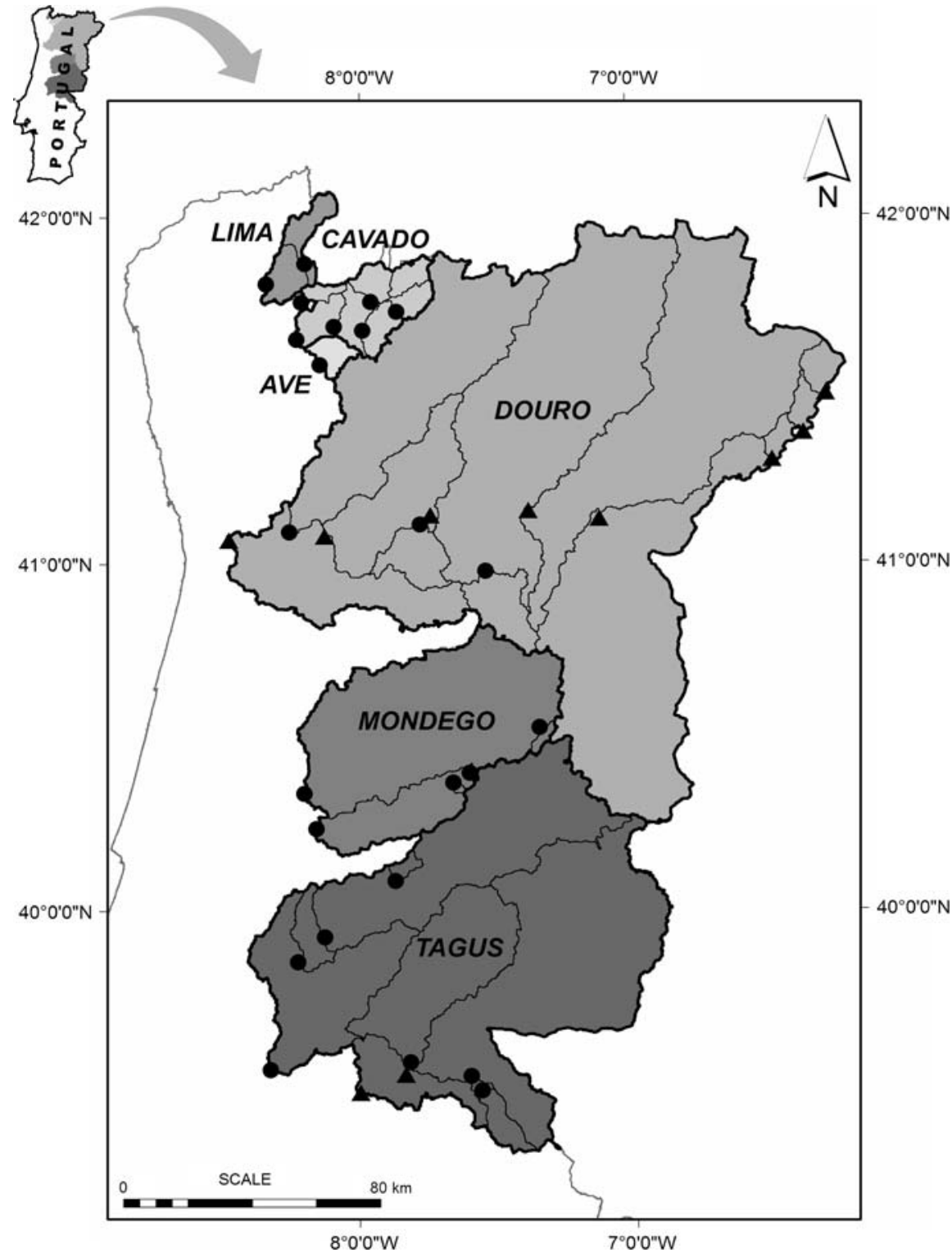

industries in the basin (number of sources ha $\mathrm{ha}^{-1}$ basin); and

(iv) Hydrometric variations-yearly water level changes were determined by the differences between relative average water level and maximum theoretical water level.

All the variables were expressed, when possible, on a per-unit area basis. Points (ii) and (iii) were determined based on data from INE (2006). A 5-score scale was established for all the variables (from 1-High status to 5-Low status). Therefore, the sum of these 
Table 1 Characterization of the 34 studied reservoirs, sampled from 1996 to 2006

\begin{tabular}{|c|c|c|c|c|c|c|}
\hline \multirow[t]{2}{*}{ Variables } & \multirow[t]{2}{*}{ Units } & \multirow[t]{2}{*}{ Code } & \multicolumn{2}{|l|}{ Type $1(n=160)$} & \multicolumn{2}{|c|}{ Type $2(n=473)$} \\
\hline & & & Mean \pm SD & Min.-max. & Mean \pm SD & Min.-max. \\
\hline \multicolumn{7}{|l|}{ Local variables $(L)$} \\
\hline Total Coliforms & $\mathrm{N} / 100 \mathrm{ml}$ & TColf & $1018 \pm 2244$ & $1.00-21000$ & $1892 \pm 8958$ & $0.00-102000$ \\
\hline Faecal Coliforms & $\mathrm{N} / 100 \mathrm{ml}$ & FColf & $78.2 \pm 419$ & $0.00-4550$ & $25.7 \pm 238$ & $0-5000$ \\
\hline Chlorophyll $a$ & $\mathrm{mg} / \mathrm{m}^{3}$ & Chl_a & $3.35 \pm 7.34$ & $0.04-53.4$ & $6.31 \pm 9.97$ & $0.04-86.0$ \\
\hline Surface water temperature & ${ }^{\circ} \mathrm{C}$ & Temp & $16.00 \pm 5.45$ & $5.9-26$ & $16.88 \pm 5.3$ & $5-28$ \\
\hline Turbidity & NTU & Turb & $3.87 \pm 7.15$ & $0.20-77.0$ & $1.73 \pm 2.68$ & $0.20-40.0$ \\
\hline $\mathrm{pH}$ & units & $\mathrm{pH}$ & $7.92 \pm 0.57$ & $6.80-9.40$ & $7.27 \pm 0.93$ & $5.70-10.2$ \\
\hline Dissolved oxygen & $\mathrm{mg} / \mathrm{l}$ & DO & $9.35 \pm 2.76$ & $1.30-18.8$ & $9.38 \pm 1.81$ & $2.50-15.0$ \\
\hline Conductivity & $\mu \mathrm{S} / \mathrm{cm}$ & Cond & $356 \pm 123$ & $168-802$ & $49.3 \pm 33.5$ & $8.40-243$ \\
\hline Hardness & $\mathrm{mg} \mathrm{CaCO}_{3} / 1$ & Hard & $138 \pm 45.1$ & $63.0-260$ & $10.0 \pm 7.86$ & $0.80-48.6$ \\
\hline Ammonia-N & $\mathrm{mg} / \mathrm{l}$ & $\mathrm{NH}_{4}$ & $0.15 \pm 0.14$ & $0.05-0.86$ & $0.14 \pm 0.44$ & $0.05-8.60$ \\
\hline Nitrate-N & $\mathrm{mg} / \mathrm{l}$ & $\mathrm{NO}_{3}$ & $5.69 \pm 3.03$ & $0.16-17.0$ & $1.18 \pm 1.28$ & $0.01-8.90$ \\
\hline Phosphate & $\mathrm{mg} / \mathrm{l}$ & $\mathrm{PO}_{4}$ & $0.25 \pm 0.21$ & $0.01-1.22$ & $0.04 \pm 0.09$ & $0.01-1.12$ \\
\hline Total phosphorus & $\mathrm{mg} / \mathrm{l}$ & $\mathrm{TP}$ & $0.38 \pm 0.22$ & $0.10-1.42$ & $0.38 \pm 2.15$ & $0.01-20.0$ \\
\hline $\mathrm{Fe}$ & $\mathrm{mg} / \mathrm{l}$ & $\mathrm{Fe}$ & $47.2 \pm 52.9$ & $3.00-500$ & $44.6 \pm 60.7$ & $3.00-710$ \\
\hline $\mathrm{Mn}$ & $\mathrm{mg} / \mathrm{l}$ & $\mathrm{Mn}$ & $14.5 \pm 13.4$ & $2.00-65.0$ & $14.1 \pm 16.5$ & $2.00-230$ \\
\hline $\mathrm{Cl}$ & $\mathrm{mg} / \mathrm{l}$ & $\mathrm{Cl}$ & $19.8 \pm 11.9$ & $7.50-74.0$ & $5.44 \pm 3.46$ & $1.20-24.2$ \\
\hline Chemical oxygen demand & $\mathrm{mg} \mathrm{O}^{2} / 1$ & COD & $8.73 \pm 5.14$ & $0.10-26.3$ & $7.13 \pm 6.23$ & $0.40-50.2$ \\
\hline 5-day Biochemical oxygen demand & $\mathrm{mg} \mathrm{O}^{2} / 1$ & $\mathrm{BOD}_{5}$ & $1.86 \pm 1.13$ & $0.10-7.90$ & $1.52 \pm 1.46$ & $0.00-12.8$ \\
\hline Dissolved reactive silica & $\mathrm{mg} / \mathrm{l}$ & DRSi & $3.77 \pm 2.83$ & $0.20-14.1$ & $4.24 \pm 2.74$ & $0.10-15.0$ \\
\hline Secchi disk depth & $\mathrm{m}$ & SD & $3.22 \pm 3.54$ & $0.10-20.8$ & $3.38 \pm 1.87$ & $0.30-10.0$ \\
\hline Chlorophyll $a$ in the hypolimnium & $\mathrm{mg} / \mathrm{m}^{3}$ & Chl_a-Hp & $2.05 \pm 7.08$ & $0.04-84.9$ & $2.48 \pm 5.54$ & $0.04-52.9$ \\
\hline Water temperature in the hypolimnium & ${ }^{\circ} \mathrm{C}$ & Temp-Hp & $14.9 \pm 4.73$ & $5.00-25.0$ & $12.5 \pm 3.55$ & $5.00-24.0$ \\
\hline Dissolved oxygen in the hypolimnium & $\mathrm{mg} / \mathrm{l}$ & DO-Hp & $6.81 \pm 3.50$ & $0.05-13.8$ & $5.70 \pm 3.54$ & $0.05-13.0$ \\
\hline Time of residence & days & TimRes & $3.61 \pm 2.88$ & $0.60-12.4$ & $108 \pm 148$ & $1.70-729$. \\
\hline Altitude & $\mathrm{m}$ & Alt & 182. \pm 197 & $13.2-528$ & $411 \pm 370$ & $50.00-1600$ \\
\hline Mean dam depth & $\mathrm{m}$ & Depth & $17.4 \pm 8.39$ & $5.61-31.9$ & $21.6 \pm 9.14$ & $8.36-42.8$ \\
\hline \multicolumn{7}{|l|}{ Regional variables $(R)$} \\
\hline Catchment area & $\mathrm{Km}^{2}$ & A & $74962 \pm 13528$ & $60000-92050$ & $943 \pm 1029$ & $5.00-3252$ \\
\hline Slope & $\%$ & Slope & $6.00 \pm 1.00$ & $5.00-7.00$ & $11.0 \pm 4.00$ & $4.00-22.0$ \\
\hline Precipitation & $\mathrm{mm}$ & $\mathrm{PP}$ & $66.0 \pm 13.3$ & $53.4-90.4$ & $135 \pm 49.0$ & $66.6-245$ \\
\hline$\%$ Urban area & $\%$ & Urban & $0.75 \pm 0.35$ & $0.30-1.39$ & $0.49 \pm 0.47$ & $0.00-1.68$ \\
\hline$\%$ Intensive agriculture & $\%$ & Int_Agr & $16.1 \pm 10.4$ & $4.04-47.0$ & $5.22 \pm 5.68$ & $0.00-19.8$ \\
\hline$\%$ Extensive agriculture & $\%$ & Ext_Agr & $33.2 \pm 12.9$ & $19.9-69.0$ & $18.9 \pm 11.3$ & $0.00-40.7$ \\
\hline$\%$ Natural areas & $\%$ & Natural & $48.4 \pm 17.6$ & $13.8-71.9$ & $72.4 \pm 14.7$ & $40.5-93.9$ \\
\hline$\%$ Burned areas & $\%$ & Burned & $0.68 \pm 0.87$ & $0.00-3.09$ & $0.62 \pm 1.14$ & $0.00-5.2$ \\
\hline$\%$ Water & $\%$ & Water & $0.89 \pm 0.58$ & $0.21-2.77$ & $2.40 \pm 3.51$ & $0.00-18.8$ \\
\hline \multicolumn{7}{|l|}{ Geographical variables $(G)$} \\
\hline Latitude & ${ }^{\circ} \mathrm{N}$ & Lat $(x)$ & $40.8 \pm 0.74$ & $39.5-41.5$ & $40.9 \pm 0.83$ & $39.5-41.9$ \\
\hline Longitude & ${ }^{\circ} \mathrm{W}$ & Long $(y)$ & $7.47 \pm 0.83$ & $6.26-8.49$ & $7.94 \pm 0.36$ & $6.89-8.35$ \\
\hline
\end{tabular}

5-score scales reflects the final ecological status of the reservoir's watershed and was classified in the following classes: I <18; II 18-22; III 22-26; IV 26-30 and
$\mathrm{V}>30$. In this study, class I and II were grouped to represent reference reservoirs, and class III, IV and V were grouped to represent impaired sites. 
Table 2 Number of taxa, samples and sites, total inertia and conditional effects (lambda) of spatial (G, R and L) scales and time on phytoplankton assemblages for all, type 1 and type 2 reservoirs

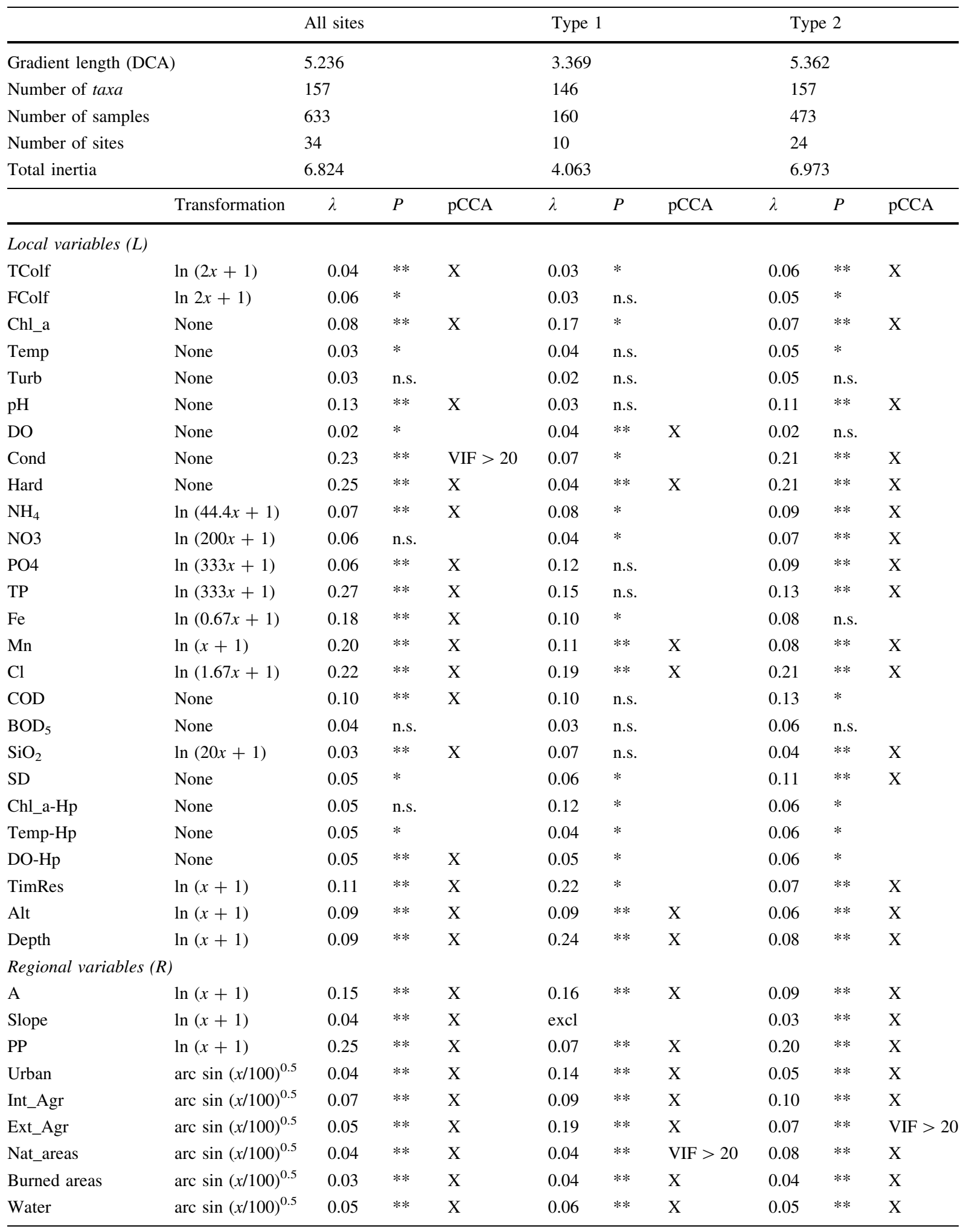


Table 2 continued

\begin{tabular}{|c|c|c|c|c|c|c|c|c|c|c|}
\hline & Transformation & $\lambda$ & $P$ & pCCA & $\lambda$ & $P$ & pCCA & $\lambda$ & $P$ & pCCA \\
\hline \multicolumn{11}{|c|}{ Geografical variables $(G)$} \\
\hline Lat & $\ln (x+1)$ & excl. & & & excl. & & & excl. & & \\
\hline Long & $\ln (x+1)$ & 0.09 & $* *$ & $X$ & 0.13 & $* *$ & $X$ & 0.10 & $* *$ & $\mathrm{X}$ \\
\hline $\mathrm{Lat}^{2}$ & $\ln (x+1)$ & excl. & & & excl & & & excl & & \\
\hline Lat*Long & $\ln (x+1)$ & 0.12 & $* *$ & $\mathrm{X}$ & 0.10 & $* *$ & $\mathrm{X}$ & excl & & \\
\hline Long $^{2}$ & $\ln (x+1)$ & 0.07 & $* *$ & $X$ & 0.10 & $* *$ & $\mathrm{X}$ & 0.06 & $* *$ & $\mathrm{X}$ \\
\hline $\mathrm{Lat}^{3}$ & $\ln (x+1)$ & 0.17 & $* *$ & $\mathrm{X}$ & 0.09 & $*$ & & 0.23 & $* *$ & $X$ \\
\hline Lat $^{2} *$ Long & $\ln (x+1)$ & 0.10 & $* *$ & $X$ & 0.08 & $* *$ & $X$ & 0.11 & $* *$ & $\mathrm{X}$ \\
\hline Lat*Long $^{2}$ & $\ln (x+1)$ & 0.08 & $*$ & & 0.09 & n.s & & 0.06 & $*$ & \\
\hline Long $^{3}$ & $\ln (x+1)$ & 0.07 & $* *$ & $\mathrm{X}$ & 0.10 & n.s & & 0.06 & $* *$ & $\mathrm{X}$ \\
\hline \multicolumn{11}{|l|}{ Time variables $(T)$} \\
\hline All sampling dates & None & 7.30 & & $\mathrm{X}$ & 27.0 & & $X$ & 9.00 & & $X$ \\
\hline
\end{tabular}

$p C C A$ Explanatory variables used in pCCAs

excl. Variable excluded because of negligible variance

* $P<0.05$; ** $P<0.001$; n.s., $P>0.05$

\section{Phytoplankton analysis}

Like the environmental parameters, phytoplankton samples were collected from 1996 to 2004 at a depth of approximately $0.5 \mathrm{~m}$ using a Van Dorn bottle. Phytoplankton community composition was studied through inverted microscopy, following Utermohl's method (Lund et al., 1958). For the quantification and identification of phytoplankton, samples were fixed in Lugol's solution (1\% v/v) and, when possible, identified to the species level. The abundance of each taxon was estimated on a 5 -score ordinal scale $(0-20 ; 20-40 ; 40-60 ; 60-80 ;>80 \%)$. A minimum of 50 random visual fields, at least 100 cells of the most common taxa were counted. Assuming that the cells were randomly distributed, the counting precision was $\pm 10 \%$ (Venrick, 1978).

\section{Statistical analysis}

Direct gradient analysis (also known as constrained ordination (ter Braak and Šmilauer, 2002), was used to determine the effect of single and combined sets of environmental variables on phytoplankton communities. Detrended correspondence analysis (DCA) of species abundance, with detrending by segments and nonlinear rescaling was used to determine the biological turnover, or gradient length, of the species datasets. Gradient lengths were then used to select the appropriate model (ordination procedure) for the constrained ordinations. DCA of taxonomic composition gave gradient lengths $>3$ standard deviations for axes 1 and 2, indicating that a unimodal response would adequately fit the species data (ter Braak, 1987). Accordingly, canonical correspondence analysis (CCA) was used in the ordination of taxonomic data (ter Braak, 1986, 1987). In CCA, phytoplankton species abundance data were not transformed because they are already scored on an ordinal scale. Rare species (less than four presences in each dam, for all the samples) were omitted from statistical analyses (Negro and De Hoyos, 2005). When necessary, environmental variables were $\ln (a x+1)$ transformed. The factor $a$ was determined for each chemical separately according to the procedure described in Van den Brink et al. (2000) (see Table 2). We deviated from the usual $\ln (x+1)$ transformation because the data set frequently showed low or high values. We decided that the factor $a$ should make 2 by taking the lowest abundance value higher than zero for $x$. A factor of two was chosen to avoid false discrepancy between zero concentration values and low concentration values (Van den Brink \& Kater, 2006). Percentage data like land use variables were arc $\sin (x / 100)^{0.5}$ transformed in order to approximate normally distributed random errors (Podani, 2000; Feld \& Hering, 2007) (Table 2). All the time variables (dummy variables) were not transformed (Table 2). 
A Person correlation matrix was performed a priori from the CCA forward selection and all the variables with correlation coefficients higher than 0.7 were eliminated from posterior analysis. Most of the hypolimnium parameters were eliminated, except temperature, DO and Chl $a$.

CANOCO's forward selection procedure (999 permutations) was used to choose the environmental variables that represented the major gradients, but did not correlate strongly with each other in explaining variability among phytoplankton assemblages. This procedure is used to remove collinear environmental variables. Environmental variables were run separately on each spatial scale (geographical, regional and local) to identify collinear variables with a variance inflation factor (VIF) $>20$. Therefore, conductivity (data set1), $\%$ of natural areas (data set 2 ) and \% of extensive agriculture (data set 3 ) were subsequently excluded from the respective environmental data set (Table 2). The significance of the environmental variables was tested with 999 Monte Carlo permutations.

A partial constrained ordination, a direct gradient analysis using co-variables can be used to partition the variance, i.e. estimate the fraction of variance in community composition explained by a set of environmental variables separately (e.g. Borcard et al., 1992). Partial CCA (pCCA) was used to evaluate the relationships between four categories of explanatory variables (geographical, regional, local and time) and community composition of phytoplankton (ter Braak and Šmilauer, 2002). Using pCCA, we partitioned the total variation of the biological response variables into: (i) the non-shared variation for a specific set of explanatory variables, (ii) shared variation by all the measured variables and (iii) random error. The use of partial constrained ordination allowed us to test the degree of correlation or, in particular, the uniqueness of the relationships between variables at varying spatial scale and community composition of phytoplankton in the two types of reservoirs. Only significant $(P<0.001)$ variables were included in the aggregations of environmental variables used in the partial constrained ordinations. All the time variables were included, since they are orthogonal, i.e. they all explain a unique part of the variance. Table 2 shows the variables included in the three spatial categories (geographical, regional and local) as well as the variance explained by the individual variables ( $\lambda_{1}$ or marginal effects). Using these data,
Fig. 2 Canonical correspondence analysis (CCA) of phytoplankton assemblages in Portuguese reservoir in the ordination space of first and second axis; (A) in all the studied reservoirs; $(\mathbf{B})$ in 10 reservoirs of Type 1 and $(\mathbf{C})$ in 24 of Type 2. (A, B and $\mathbf{C}$ ) ordination of sampling sites, (A1, B1 and C1) ordination of phytoplankton taxa. Only significant and independent environmental variables are shown. Full environmental variable and phytoplankton taxa names are given in Table 1 and Appendix 1-Supplementary material, respectively

pCCA was run for phytoplankton community composition of lowland and high altitude reservoirs according to Borcard et al. (1992) and Liu (1997). Three steps were used to partition the variance in the reservoir phytoplankton data among the three levels of spatial scale and time, i.e. geographical (G), regional $(\mathrm{R})$, local $(\mathrm{L})$ and time $(\mathrm{T})$.

First, canonical ordination with no covariables (i.e. CCA) was used to estimate the total amount of variance explained (as sum of canonical eigenvalues) in the phytoplankton communities attributable to all the explanatory variables (GRLT) and the total unexplained variance $(1-$ GRLT). A second series of ordinations with covariables (i.e. pCCA) was used to calculate variance explained by the unique effects of each category (G, R, L or T). In this step, ordinations of individual explanatory categories were run (e.g. G) with the remaining three categories as covariables (e.g. $\mathrm{R}+\mathrm{L}+\mathrm{T}$ ). Thirdly, a series of partial canonical ordinations were used to calculate the shared effects by the selected predictors (e.g. $\mathrm{R}+\mathrm{L}+\mathrm{T}-\mathrm{G}$ ) by running the interaction term of interest as explanatory $(\mathrm{R}+\mathrm{L}+\mathrm{T})$ and removing the effect of the term not of interest (e.g. G) by running these variables as covariables. All the ordinations were run using CANOCO 4.5 (ter Braak and Šmilauer, 2002).

\section{Results}

Phytoplankton composition

In the 633 phytoplankton samples a total of 250 taxa were identified. From these, 93 taxa occurred less than four times in each reservoir and were excluded from the dataset (see methods). The remaining 157 taxa belonged to six divisions. Most important in terms of number of taxa were Chlorophyta $(41 \%$ of the taxa), Bacillariophyta (29\%) and Cyanobacteria $(20 \%)$. There were eight taxa of Crysophyta (5\%) and 

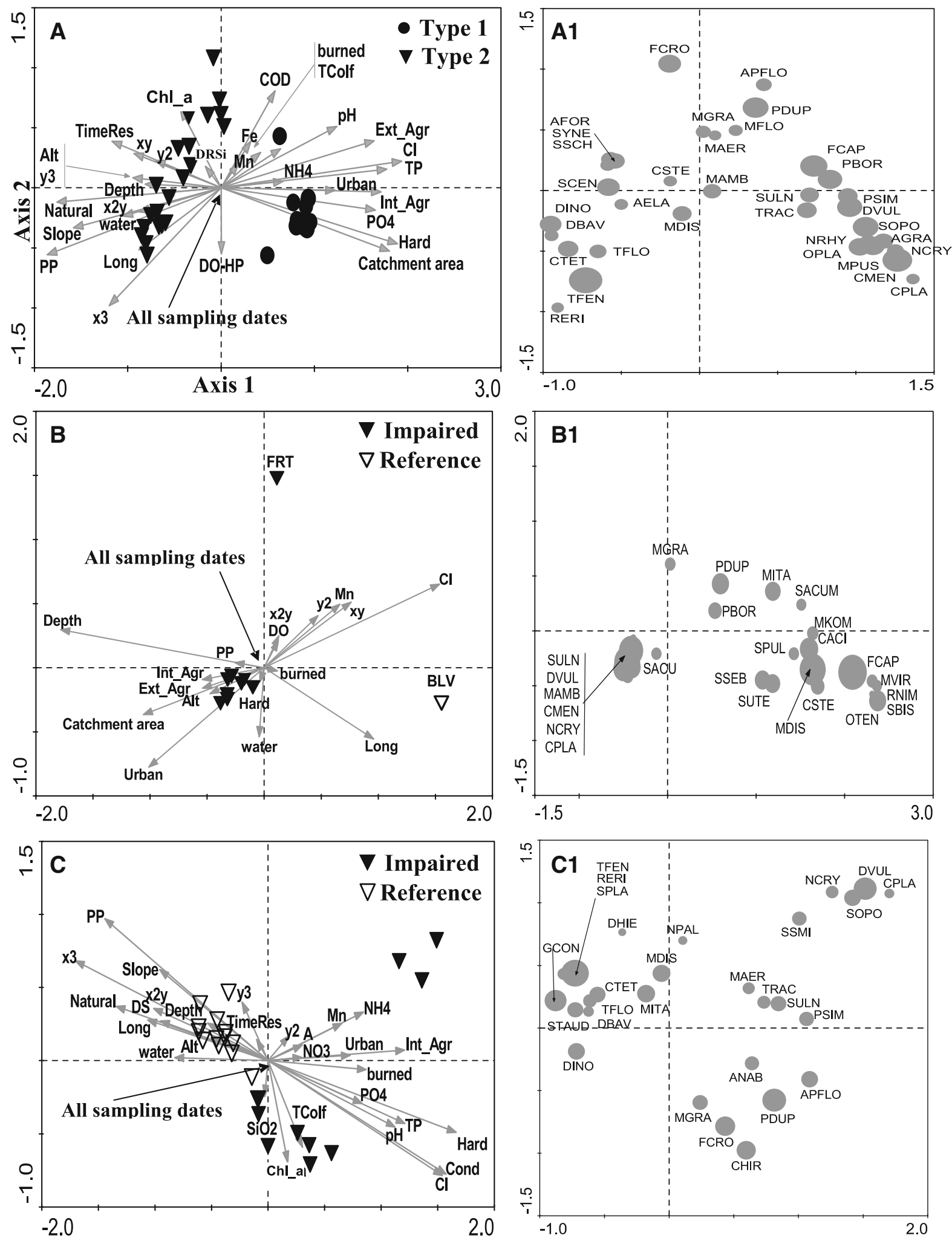
three taxa of Dinophyta as well as of Euglenophyta (representing each $2 \%$ of the total taxa).

Environmental gradients and their relation to phytoplankton taxa (CCA models)

The CCA models with all the selected environmental variables explained 27,28 and $50 \%$ of the variance in phytoplankton reservoirs communities in data set 1 (with all reservoirs), data set 2 (Type 1) and data set 3 (Type 2), respectively (Fig. 2, Table 3). In the three data sets, the CCA models run separately on each spatial scale explained $6.6-13 \%$ by geographical variables $(\mathrm{G}), 9.3-19 \%$ by regional variables $(\mathrm{R}), 13-$ $19 \%$ by local variables (L) and $7.3-27 \%$ by Time (T) of the variance in the reservoirs communities (Table 3). In general, local and regional scales explained the majority of the variance in the studied phytoplankton communities, although less pronounced for Type 1 reservoirs. In these lowland reservoirs, time variables explained the largest part of the variation in species composition (Table 3 ).

In data set 1 , the separation between the two types of reservoirs results mainly from the environmental variables correlated with the first CCA axis (Fig. 2A). Type 1 reservoirs were positively correlated with axis 1, mostly related to a perturbation gradient due to organic pollution (COD), nutrients concentration (TP, $\mathrm{PO}_{4}{ }^{3-}$ and $\left.\mathrm{NH}_{4}{ }^{+}\right), \mathrm{Cl}^{-}$and $\mathrm{pH}$. In general, these reservoirs presented larger watersheds dominated by agriculture, with significant urban and burned areas (Fig. 2A). Both reservoir types were clearly dominated by Bacillariophyta and Chlorophyta. Cyclotella meneghiniana, Fragilaria capucina, Diatoma vulgaris, Pediastrum duplex, P. boryanum, Navicula rhynchocephala, N. cryptocephala, Cocconeis placentula and the Cyanobacteria Aphanizomenon flosaquae, Microcystis flos-aquae and M. aeruginosa, were positively correlated with Type 1 reservoirs and the perturbation gradient, i.e. with the first CCA axis (Fig. 2A1).

Type 2 reservoirs were negatively correlated with the first CCA axis and positively with precipitation, $\%$ of natural areas, slope, altitude, residence time, geographical variables and depth. The separation between reference and impaired sites of Type 2 reservoirs results mainly from the environmental variables correlated with the second axis, namely dissolved oxygen of the hypolimnium (OD-HP), chlorophyll $a$ and DRSi (Fig. 2A). Therefore, related with impaired sites of Type 2 reservoirs and negatively correlated with first axis and positively with the second axis were Fragilaria crotonensis, Asterionella formosa, Synedra spp., Cyclotella stelligera, Sphaerocystis schroeteri. Contrarily, Tabellaria fenestrata, T. flocculosa, Aulacoseira distans, Rhizosolenia eriensis, Crucigenia tetrapedia, Dinobryon sp., D. bavaricum and Aphanocapsa elachista were related with reference sites of Type 2 reservoirs and negatively correlated with first and second CCA axes, i.e. negatively correlated with the pollution gradient (Fig. 2A1).

In Type 1 reservoirs, the separation between the impaired and less-disturbed reservoirs results mainly from the environmental variables correlated with the first axis (Fig. 2B). Less-disturbed reservoirs of Type 1, namely Belver, was positively correlated with longitude and $\mathrm{Cl}^{-}$and negatively to depth and precipitation gradients, whereas impaired reservoirs were negatively correlated with axis 1 and positively

Table 3 Results of multivariate regression models of taxa (CCA) with environmental variables at different spatial scales

\begin{tabular}{|c|c|c|c|c|c|c|c|c|c|c|c|c|c|c|c|}
\hline & \multicolumn{5}{|c|}{ All sites } & \multicolumn{5}{|l|}{ Type 1} & \multicolumn{5}{|l|}{ Type 2} \\
\hline & GRLT & G & $\mathrm{R}$ & $\mathrm{L}$ & $\mathrm{T}$ & GRLT & $\mathrm{G}$ & $\mathrm{R}$ & $\mathrm{L}$ & $\mathrm{T}$ & GRLT & G & $\mathrm{R}$ & $\mathrm{L}$ & $\mathrm{T}$ \\
\hline No. environmental of total variables & 78 & 9 & 9 & 26 & 34 & 78 & 9 & 9 & 26 & 34 & 78 & 9 & 9 & 26 & 34 \\
\hline No. environmental variables selected & 65 & 6 & 9 & 16 & 34 & 51 & 4 & 7 & 6 & 34 & 63 & 5 & 8 & 16 & 34 \\
\hline $\begin{array}{l}\% \text { Variance explained by the } \\
\text { environmental variables }\end{array}$ & 27 & 7.9 & 11 & 13 & 7.3 & 50 & 13 & 18 & 19 & 27 & 28 & 6.6 & 9.3 & 13 & 9.0 \\
\hline $\begin{array}{l}\% \text { Variance of species-environment } \\
\text { relationship explained by axes } 1 \text { and } 2\end{array}$ & 32 & 71 & 64 & 53 & 31 & 38 & 77 & 71 & 72 & 27 & 27 & 72 & 58 & 43 & 32 \\
\hline $\begin{array}{l}\% \text { Variance of species data explained } \\
\text { by axes } 1 \text { and } 2\end{array}$ & 9 & 6 & 7 & 7 & 2 & 16 & 10 & 12 & 13 & 7 & 8 & 5 & 5 & 5 & 3 \\
\hline
\end{tabular}


with depth, \% of urban and agricultural areas, catchment area and altitude. In general, these mostperturbed reservoirs presented larger watersheds, belonging to international basins like Douro and Tagus, dominated by agriculture and having significant urban areas (Fig. 2B). Associated with Belver, were Fragilaria capucina, Aulacoseira distans, Synedra pulchella, S. utermohlii, Cyclotella stelligera, Surirella biseriata, Closterium aciculare, Staurastrum sebaldi, Mougeotia sp., Radiococcus nimbatus and Limnothrix tenuis. (Fig. 2B1). Mostimpaired sites of Type 1 reservoirs were negatively correlated with axis 1 , i.e. positively associated with an anthropogenic pressure gradient and associated with meso-eutrophic to hypereutrophic taxa (Van Dam et al., 1994; Tavassi et al., 2004), namely Diatoma vulgaris, Aulacoseira ambigua, Cyclotella meneghiniana, Navicula cryptocephala, Synedra ulna, S. acus and Limnothrix planctonica (Fig. 2B1).

As in Type 1, in higher altitude reservoirs (Type 2) the separation between reference and impaired sites results mostly from the environmental variables correlated with the first axis (Fig. 2C). Sites on the right side of the first $\mathrm{CA}$ axis lay in densely populated, industrialized or agricultural areas, receiving high inputs of organic matter and industrial discharge. Therefore, these sites were positively correlated with water mineral content $(\mathrm{Cl}$, hardness and conductivity), nutrients ( $\mathrm{P}$ and $\mathrm{N}$ ) and organic pollution gradients (Fig. 2C). In general, these disturbed sites were clearly dominated by tolerant taxa of Bacillariophyta and Chlorophyta, mainly associated from meso-to-hypereutrophic states of water bodies (Van Dam et al., 1994; Tavassi et al., 2004): Diatoma vulgaris, Synedra ulna, Navicula cryptocephala, Nitzschia palea, Cocconeis placentula, Fragilaria crotonensis, Aulacoseira granulata, Pediastrum simplex and $P$. duplex. These taxa appear associated with Cyanobacteria belonged mostly to genera whose ability to produce toxins that can affect a variety of organisms, including humans is known, like Microcystis aeruginosa, Aphanizomenon flosaquae and Anabaena spp. (Dokulil \& Teubner, 2000; Vasconcelos, 2001) (Fig. 2C1). Reference sites of Type 2 were negatively correlated with the first CCA axis and positively with precipitation, geographical variables (latitude ${ }^{3}$, longitude ${ }^{3}$, longitude, latitude $^{2} *$ longitude), $\%$ of natural areas, slope, altitude, Secchi depth and depth (Fig. 2C). Negatively correlated with axis 1 and associated with reference sites were mainly intolerant taxa, Diatoma hiemale, Tabellaria fenestrata, T. floculosa, Aulacoseira distans, M. italica, Rhizosolenia eriensis, Gomphonema sp., Crucigenia tetrapedia, Spondylosium planum, Dinobryon sp. and D. bavaricum (Fig. 2C1).

Relative importance of spatial versus time factors

Variance partitioning-CCA

The marginal or individual variances explained by single environmental variables (with no covariables) are shown in Tables 2 and 3. In general, local variables explained a large amount of the among-reservoirs variance in both lowland and higher altitude reservoirs. In lowland reservoirs (Type 1), local variables were only exceeded by the time variables. Regional variables explained a similar amount of the total variance as local variables, while geographical variables explained less (Table 3). The single best predictors of phytoplankton communities in Type 1 reservoirs were depth, $\%$ of extensive agriculture, longitude and sampling dates, in local, regional, geographical and temporal scales, respectively (Table 2).

In general, environmental variables explained less of the among-reservoir differences in community types of higher altitude compared with lowland reservoirs. Local variables explained the largest part of the variance, followed by regional, time and geographical factors (Table 3). Similar results were obtained with data set 1 , with all the studied reservoirs (Table 2). The best predictors of phytoplankton assemblages in Type 2 reservoirs were conductivity, hardness and $\mathrm{Cl}$, precipitation, latitude ${ }^{3}$ and sampling dates, in local, regional, geographical and temporal scales, respectively (Table 2).

\section{Variance partitioning $-p C C A$}

Analysis of CCA models and the variance explained by single predictor variables showed the importance of geographical, regional, local and time factors on among-site differences in phytoplankton communities. However, this approach does not provide information on the unique effect or shared variance (conditional effects) among the different types of predictor variables. The three categories of spatial scale and time $(G, R, L, T)$ explained $50 \%$ of the 
among-site variance in community composition of lowland reservoirs (Table 3, Fig. 3A). For higher altitude reservoirs, the amount of variance explained was smaller; 28\% (Table 3, Fig. 3C). Partial constrained ordination (pCCA) of lowland and higher reservoir communities showed that the unique effect of geographical, regional and local variables was similar among the two types studied, explaining slightly more variance in Type 2 (Table 3, Fig. 3A, C). However, time variables assumed a major importance in explaining among-site differences in phytoplankton community composition, namely in Type 1 reservoirs.

Geographical variables explained $2.6 \%$ for lowland reservoirs and $2.9 \%$ for higher altitude reservoirs. Regional variables explained slightly more of the among-site differences in community composition. The amount of variance explained by local-scale variables ranged from $3.3 \%$ (in Type 1) to $5.6 \%$ (in Type 2 reservoirs). By contrast, time variables explained substantially more of the among-site variance in community composition (Fig. 3A, C). The amount of shared variance accounted by the three levels of spatial scale and time also varied markedly between reservoir groups. The total shared variance explained substantially more, of the variance in phytoplankton communities, in type 1 than in type 2 reservoirs (Fig. 3A, C). The role of shared (conditional) effects is even clearer if separately calculated at each scale (Fig. 3B, D). In lowland reservoirs (Type 1), at geographical, regional and local scales, shared effects were much higher than unique effects (see Fig. 3B). In higher altitude reservoirs at these spatial scales $(G, R$ and $L)$ unique and shared effects were similar. Contrarily, the fraction of the total variance attributed to time variables was $21.4 \%$ in lowland sites and $7.3 \%$ in higher altitude sites (Fig. 3D). The value of the shared effects for both reservoirs was much smaller than the fraction of the variation explained independently by covariables.

Not all the species are equally well explained by the same set of environmental variables. The fit for species can be used as a measurement to find out which species are well represented and the percentage of variance fit by each set of explanatory variables. The percentage of variance explained by the three spatial factors and time with respect to the unconstrained variance differs among the different species (Appendix 1-Supplementary material). In Type 1 reservoirs, all the taxa are best explained by time factors, especially Pseudanabaena
Fig. 3 Variance

partitioning of

phytoplankton communities (pCCA) in reservoirs of

Type $1(\mathbf{A}, \mathbf{B})$ and Type 2

$(\mathbf{C}, \mathbf{D})$ using environmental variables at three spatial scales and time. In $\mathbf{A}$ and $\mathbf{C}$, overall joint effects were not further subdivided. In $\mathbf{B}$ and $\mathbf{D}$, Unique (gray bars) and joint (black bars) effects are given separately for each scale: time $(\mathrm{T})$, local (L), regional (R) and geographical (G). GRTL represents variance explained by all the environmental variables

catenata, P. limnetica. Limnothrix planctonica and Microcystis flos-aquae. In Type 2 reservoirs, Scenedesmus spp. had their distributions mostly explained by the geographical factors. Scenedesmus opoliensis, Asterionella formosa, Cyclotella meneghiniana and Tabellaria floculosa were amongst the most related to the regional group of variables (Appendix 1-Supplementary material). Local variables explained mostly the distribution of Stephanodiscus hantschii, Anabaena spp, Limnothrix limosa, Pediastrum duplex, Rhizosolenia sp, Anabaena spp, Cocconeis placentula. Gomphonema constrictum, Microcystis pulverea, M. aeruginosa and Aulacoseira varians were amongst the most related to time variables in higher altitude reservoirs. Finally, Aulacoseira distans, Diatoma vulgaris and Fragilaria crotonensis were mostly explained by the three spatial factors (Appendix 1-Supplementary material). Figure 4 presents the taxa most well represented (higher fit) in each set of explanatory variables $(G, R$ and $L)$ for both reservoir types. In Type 1, independently of the scale in general, impaired sites were clearly dominated by tolerant taxa of Bacillariophyta and Chlorophyta, mainly associated from meso-to-hypereutrophic states of water bodies. Contrarily, reference sites were dominated by oligotrophic to meso-eutrophic taxa (Fig. 4). In Type 2, disturbed reservoirs were also dominated by tolerant taxa of Bacillariophyta namely Fragilaria capucina and Navicula cryptocephala and Chlorophyta, mostly Scenedesmus sp. and Cyanobacteria. Regarding reference sites of Type 2, dominant taxa were mainly intolerant (oligotrophic to oligo-mesotrophic), $\mathrm{Ta}$ bellaria fenestrata, T. flocculosa, Asterionella formosa, and Rhizosolenia sp (Fig. 4).

\section{Discussion}

Several studies have addressed the role of spatial and temporal scales in river and lake environmentcommunity relationships (Pan et al., 2004; Leira \& Sabater, 2005; Feld \& Hering, 2007; Jonhson et al., 2007; Holopainen et al., 2008). However, only few phytoplankton studies considered spatial factors explicitly (see Soininen, 2007), especially in reservoirs (Sabater \& Nolla, 1991; Negro and De Hoyos, 2005; INAG, 2006). Multivariate analyses allowed defining the importance of environmental variables at different spatial scales (geographical, regional and local) and time in structuring phytoplankton communities in different types of surface waters from North and Centre of Portugal. From the studied 34 hydroelectric-power reservoirs, it was possible to identify two types of dammed water bodies. Type 1 -represent lowland reservoirs located in the main rivers (Douro and Tagus) characterized by higher concentrations of nutrients and water mineral content. This "riverine reservoirs" Type more resembles a river than a lake with short hydraulic retention times, good mixing and relatively high water velocities, never or rarely affected by stratification phenomena. In general, it lay in densely populated, industrialized or agricultural areas, receiving high inputs of organic matter and industrial discharge;

Type 2-represent deeper high altitude "artificial lake reservoirs", largely located in tributaries, with a high residence time where water storage and release cycles are long and operate on at least seasonal cycles but generally on multi-year cycles, therefore are strongly affected by stratification phenomena.

This study has identified distinct gradients along which phytoplankton assemblage structure changes within hydroelectric Portuguese reservoirs. The differences detected among reservoir phytoplankton communities indicated that taxa compositions were differentially structured by factors related to geographic location, catchment land use, hydromorphological variables and time. Given the broad spatial gradients studied here, it was expected that constrained ordination and CCA models showed a larger importance of geographical (latitude, longitude) variables in explaining among-site differences in community composition. On the other hand, there was only a little amount of variance explained by geographical factors and only one single spatial coordinate (or combination thereof) was among the best predictors of phytoplankton assemblage (Tables 2 and 3). Local and regional (e.g. land use) factors explained a larger part of the among-site variance in phytoplankton community composition. The best predictors were: depth, residence time, $\mathrm{Cl}^{-}$, chlorophyll $a$ and nutrient gradients at local scale (L) and $\%$ of extensive agriculture, $\%$ of urban area and catchment area at regional scale $(\mathrm{R})$, for Type 1 reservoirs. Conductivity, hardness and $\mathrm{Cl}^{-}$and $\mathrm{TP}$ gradients (L), precipitation, \% of intensive agriculture (R) and latitude and latitude ${ }^{2}$ (at a geographical scale) 
were shown to be strong predictors of community structure in Type 2 reservoirs.

Conductivity, hardness, $\mathrm{N}$ and $\mathrm{P}$ concentrations were strongly related to agricultural activity this was not too surprising given the wide range of agricultural land use in both the lowland and higher catchments, namely extensive (19\% and 33\%, in Type 2 and type 1 , respectively) and intensive agriculture $(5.2 \%$ in Type 2 and $16 \%$ in Type 1). The importance of local and, to some extent, even regional variables agrees with a number of previous studies, even for different organisms. For example, earlier studies have shown changes of nutrient concentration, habitat and flow regime, often associated with changes in catchment land use/cover, to be good predictors of fish (e.g. Snyder et al., 2003; INAG, 2006), macroinvertebrate (e.g. Statzner et al., 2001; Death \& Joy, 2004), macrophyte (e.g. INAG, 2006) and benthic diatom (e.g. Lim et al., 2007) communities.

The influence of land use on water quality in streams and reservoirs is scale dependent and varies in time and space (Buck et al., 2004). Numerous studies have found the landscape structure to be the main factor influencing the nutrient and organic matter runoff from watersheds. This has been shown at the global scale, as well as at the regional and local scales for catchments of dominatingly agricultural use, for forested areas and for heterogeneous multifunctional landscapes (Chen et al., 2002; Buck et al., 2004).

Many reservoir researches have traditionally focussed on the effects of species interactions at small spatial scales (e.g. Lancaster \& Belyea, 2006). However, in recent years there has been a growing interest in better understanding of landscape-level effects on ecosystem structure and function; an interest fuelled in part by managers wanting to design more effective monitoring and conservation programmes.

Reservoir's communities are structured by processes operating over multiple spatial scales (e.g. Negro and De Hoyos, 2005). These interactions between scale-related processes are, however, often correlated and predictable which has resulted in a number of hierarchical frameworks (Frisell et al., 1986).

The variance decomposition technique used in this work (pCCA) allowed us to determine the unique effect of geographical, regional and local level (as well as time variables) descriptors on community composition by running spatial and time factors as co-variables.
Fig. 4 Partial Canonical Correspondence Analysis for the two types of reservoirs, with 157 taxa and environmental variables at three different spatial scales: geographical $(G)$, regional $(R)$ and local (L). 1 and 2 refer to reservoirs of type 1 and 2 , respectively. Full environmental variable and phytoplankton taxa names are given in Table 1 and Appendix 1-Supplementary material, respectively. Only taxa with higher fit and best correlated with axis one are shown

The unique variance explained by geographical variables (G) was similar among the two reservoir types (3\%, approximately), regional-level factors explained slightly more in Type 2 (3.7-4.5\%), since this higher altitude reservoirs were distributed across a broader latitudinal gradient than lowland reservoirs. Local scale factors explained slightly more of the variance in community structure among sites $(3.3 \%$ and $5.6 \%$, in Type 1 and 2, respectively). These results lend support to a number of previous studies (e.g. Leira \& Sabater, 2005; INAG, 2006; Lim et al., 2007; Soininen, 2007). By contrast, time factors explained the highest amount of variance in community structure among sites (from 7.3 to $21 \%$ ), but surprisingly as single predictors sampling dates only explained $0.2-1.5 \%$ in Type 1 and even less in Type $2(0.1-0.6 \%)$. This could be related to the higher number of time variables used in the analysis (34) when compared to other variable factors (4-5 variables in G, 7-8 in $\mathrm{R}$ and $6-16$ in $\mathrm{L}$ factor). This is corroborated by the fact that after accounting for time effects (by running this variable as covariable), the spatial factors ( $G, R$ and $L)$ explained a similar amount of variance in Type 1 reservoirs $(21 \%$ and $22 \%$ explained by time and spatial scales, respectively). In Type 2, spatial factors together explained a larger amount of variance in phytoplankton composition among sites than time, $19 \%$ vs. $7.3 \%$, respectively). Nevertheless, with the same number of variables used in the analysis, time explained much more of the variance in community structure in Type 1 than in Type 2 reservoirs, probably related to the management of reservoirs. "Run-of-river" reservoirs (Type 1), with very low residence time (days), presenting lesser stability conditioned by meteorological or hydrological conditions (directly associated with variations along the year and to seasons), than reservoirs which are explored as true reservoirs (Type 2), with relatively high residence time (GIG, 2007).

Regardless of how different sets of variables are classified, our results and those of earlier studies are 
TYPE 1
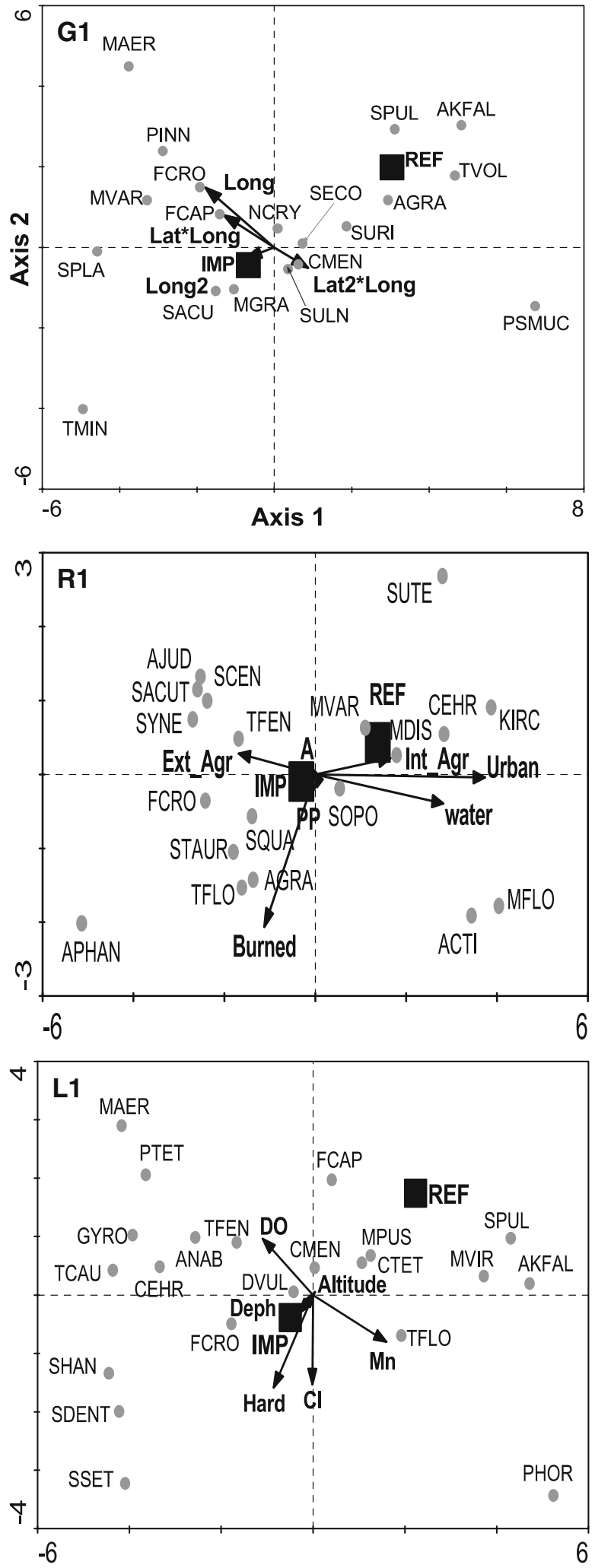

TYPE 2
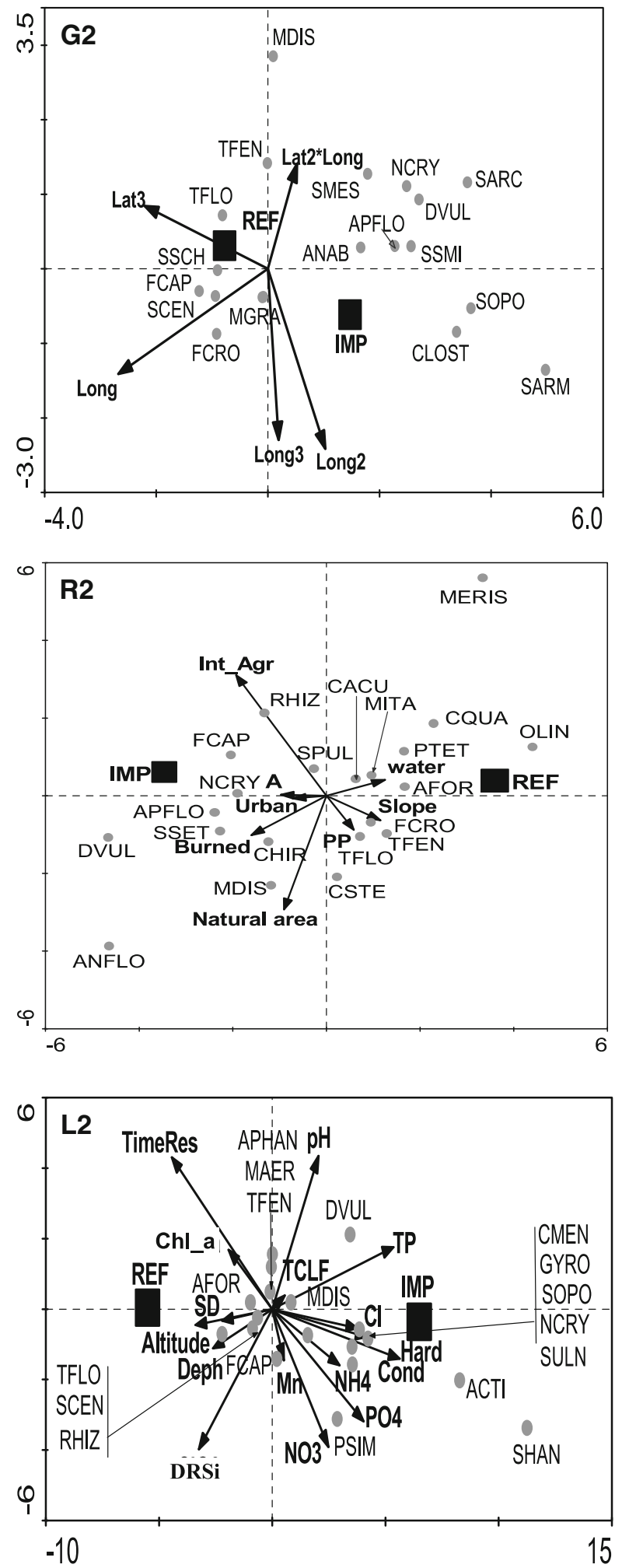
consistent with hierarchy theory; namely that species composition at a site is the product of environmental filters operating at successive spatial scales (Poff, 1997). Frisell et al. (1986), defined the "hierarchical concept of landscape", where spatial scales are related or even interdependent, at least unidirectionally from large to small spatial scales. This was reflected in our study by the strong shared effects of spatial scales in both the reservoir types. The amount of shared variance accounted for by the three levels of spatial scale and time varied markedly between reservoir groups. The total shared variance accounted for $18 \%$ and $7.6 \%$, in Type 1 and Type 2, respectively (Fig. 3). The role of shared (conditional) effects is even clearer when separately calculated at each scale (Fig. 3). For G, R and L factors, shared effects were much higher than unique effects in Type 1 and very similar in Type 2. Contrarily, for time variables, the percentage of the total variance explained was $21 \%$ and $7.3 \%$ on Type 1 and 2, respectively. Since the value of the shared effects for both reservoirs was much smaller than the fraction of the variation explained independently by co-variables, we can conclude that time variables were primarily explaining unique variation in species composition.

A number of recent publications have stressed that phytoplankton communities seem to be relatively strongly spatially structured across multiple spatial scales (Fallu et al., 2002; Clarke et al., 2005; INAG, 2006; Soininen, 2007). According to these studies, pure spatial factors account for an important amount of the community variation at geographical and regional scales. This important fraction of variation probably can not be explained by local abiotic factors (Soininen, 2007).

Not all species are equally well explained by the same set of environmental variables, as shown in this study (see Appendix 1-Supplementary material). The fit for species can be used as a measurement to find out which species are well represented and the percentage of variance fit by each set of explanatory variables (Leira \& Sabater, 2005). Nevertheless, phytoplankton composition responds to a clear disturbance gradient. In general, disturbed sites were clearly dominated by tolerant taxa of Bacillariophyta and Chlorophyta. Therefore, in both reservoirs, mesoeutrophic-to-hypereutrophic taxa (Van Dam et al., 1994; Tavassi et al., 2004), namely Cocconeis placentula, Cyclotella meneghiniana, Diatoma vulgaris, Aulacoseira ambigua, Navicula cryptocephala, Nitzschia palea, Synedra ulna and S. acus were positively associated with an anthropogenic pressure gradient. Contrarily, the taxa associated with reference sites were mainly intolerant (oligotrophic to oligomesotrophic) taxa: Diatoma hiemale, Tabellaria fenestrata, T. floculosa, Aulacoseira distans, M. italica, Rhizosolenia eriensis and Gomphonema constrictum (Van Dam et al., 1994; Tavassi et al., 2004).

Disagreements regarding which factors are directly related to reservoirs communities might emanate in part from the study design, as studies at different spatial and temporal scales are prone to give different answers (Wiley et al., 1997) or be an artefact of how the various studies have classified variables of spatial scale.

Not only scale-related effects, but a number of other factors should be considered when selecting response variables or organism group(s) to monitor the effects human-induced stress on reservoirs integrity (e.g. Rosenberg \& Resh, 1993). Ideally, focus should be on selecting response variables that are related causally and/or strongly associated (proximate indicator) with the type and degree of perturbation to be monitored (e.g. Downes et al., 2002). Phytoplankton seem to be a good indicator for multi-scale and cumulative disturbance effects with a view to integrate future worldwide monitoring in reservoirs. However, we must point out that there is a lack of information for a great number of phytoplankton species, namely concerning individual autoecology (Tavassi et al., 2004; Tolotti et al., 2006). Nevertheless, great efforts have been made in this direction (Reynolds et al., 2002; Borges et al., 2008; Çelik \& Ongun, 2008; Padisák et al., 2006, 2009). With this study, we try to contribute to the understanding of species-environmental relations and ecological responses of phytoplankton communities in aquatic ecosystems, namely in artificial water bodies.

\section{Conclusions}

Combining conceptual models and empirical data is a cost-effective means of designing robust monitoring programmes. Here, we studied the phytoplankton communities commonly used in monitoring programmes across Europe as well as elsewhere to determine their response to three levels of spatial 
scale and time. The effects of different spatial scales on phytoplankton communities were clearly interrelated; thus, implying that phytoplankton assemblages are capable of detecting stress from catchment to site scales. Scaling of hydromorphological stress and relation to the reservoir phytoplankton community are current topics in applied aquatic ecology. In Europe, WFD has led to increased efforts to develop reservoir quality assessment systems. These assessment systems are an integral part of future River basin Management plans, which aims at rehabilitating and/or maintaining the biological and functional integrity of rivers, and respective reservoirs. A fundamental understanding of community function is needed to meet these objectives. Our findings of the importance of local and regional scale factors on community structure of reservoirs lend support to earlier studies, namely on the growing body of literature arguing on the importance of habitat and large-scale (landscape) factors on reservoir ecosystems. Additional studies are required to understand the relation between phytoplankton community and human impact, particularly with respect to hydrological stress, directly related to the management of reservoirs.

Acknowledgements This study was carried out within the framework of collaboration agreements between INAG (National Water Institute) and other universities, namely the UTAD (University of Trás-os-Montes e Alto Douro) for the study of Portuguese reservoirs. We would like to thank the LABELEC staff for the environmental and phytoplankton data, namely to Eng ${ }^{\circ}$. Lourenço Gil. The authors also thank the anonymous reviewers, and the Editor who helped to improve the manuscript.

\section{References}

APHA, 1995. Standard Methods for the Examination of Water and Wastewater, 19th ed. American Public Health Association, Washington, DC.

Borcard, D., P. Legendre \& P. Drapeau, 1992. Partialling out the spatial component of ecological variation. Ecology 73 : 1045-1055.

Borges, P. A. F., S. Train \& L. C. Rodrigues, 2008. Spatial and temporal variation of phytoplankton in two subtropical Brazilian reservoirs. Hydrobiologia 607: 63-74.

Brazner, J. C., N. P. Danz, G. J. Niemi, R. R. Regal, A. S. Trebitz, R. W. Howe, J. M. Hanowski, L. B. Johnson, J. J. H. Ciborowski, C. A. Johnston, E. D. Reavie, V. J. Brady \& G. V. Sgro, 2007. Evaluation of geographic, geomorphic and human influences on Great Lakes wetland indicators: a multi-assemblage approach. Ecological Indicators 7: 610-635.

Buck, O., D. K. Niyogi \& C. R. Townsend, 2004. Scaledependence of land use effects on water quality of streams in agricultural catchments. Environmental Pollution 130: 287-299.

Cabecinha, E., R. Cortes, J. A. Cabral, T. Ferreira, M. Lourenço \& M. A. Pardal, 2009. Multi-scale approach using phytoplankton as a first step towards the definition of the ecological status of reservoirs. Ecological Indicators 9(2): 240-255.

Çelik, K. \& T. Ongun, 2007. The relationships between certain physical and chemichal variables and the seasonal dynamics of phytoplankton assemblages of two inlets of a shallow hypertrophic lake with different nutrient inputs. Environmental Monitoring and Assessment 124: 321-330.

Çelik, K. \& T. Ongun, 2008. Spatial and temporal dynamics of the steady-state phytoplankton assemblages in a temperate shallow hypertrophic lake (Lake Manyas, Turkey). Limnology 9: 115-123.

Chen, L. D., B. J. Fu, S. R. Zhang, J. Qiu, X. D. Guo \& F. L. Yang, 2002. A comparative study on nitrogen-concentration dynamics in surface water in a heterogeneous landscape. Environmental Geology 42: 424-432.

Clarke, G., M. Kerman, A. Marchetto, S. Sorvari \& J. Catalan, 2005. Using diatoms to assess geographical patterns of change in high-altitude European lakes from pre-industrial times to the present day. Aquatic Sciences 67: 224-236.

Danz, N. P., G. J. Niemi, R. R. Regal, T. P. Hollenhorst, L. B. Johnson, J. M. Hanowski, R. P. Axler, J. J. H. Ciborowski, T. Hrabik, V. J. Brady, J. R. Kelly, J. C. Brazner, R. W. Howe, C. A. Johnston \& G. E. Host, 2007. Integrated gradients of anthropogenic stress in the U.S. Great Lakes basin. Environmental Management 39: 631-647.

Death, R. G. \& M. K. Joy, 2004. Invertebrate community structure in streams of the Manawatu-Wanganui region, New Zealand: the roles of catchment versus reach scale influences. Freshwater Biology 49: 982-997.

Dokulil, M. T. \& K. Teubner, 2000. Cyanobacterial dominance in lakes. Hydrobiologia 438: 1-12.

Downes, B. J., L. A. Barmuta, P. G. Fairweather, D. P. Faith, M. J. Keought, P. S. Lake, B. D. Mapstone \& G. P. Quinn, 2002. Monitoring Ecological Impacts Concepts and Practice in Flowing Waters. Cambridge University Press, Cambridge: 434.

Dziock, F., K. Henle, F. Foeckler, K. Follner \& M. Scholz, 2006. Biological indicator systems in floodplains-a review. International Review of Hydrobiology 91: 271-291.

European Commission, 2000. Directive 2000/60/EC of The European Parliament and of the Council-Establishing a Framework for Community Action in the Field of Water Policy. Brussels, Belgium, 23 October 2000.

Fallu, M. A., N. Allaire \& R. Pienitz, 2002. Distribution of freshwater diatoms in 64 Labrador (Canada) lakes: species-environment relationships along latitudinal gradients and reconstruction models for water colour and alkalinity. Canadian Journal of Fisheries and Aquatic Sciences 59: 329-349.

Feld, C. K. \& D. Hering, 2007. Community structure or function: effects of environmental stress on benthic 
macroinvertebrates at different spatial scales. Freshwater Biology 52: 1380-1399.

Frisell, C. A., W. L. Liss, C. E. Warren \& M. D. Hurley, 1986. A hierarchical framework for stream habitat classification: viewing streams in a watershed context. Environmental Management 10: 199-214.

GIG, 2007. Lake Mediterranean GIG. Joint Research Centre, European Commission. URL: http://circa.europa.eu/Public/ irc/jrc/jrc_eewai/library?l=/milestone_reports/milestone_ reports_2007/lakes\&vm=detailed\&sb=Title.

Holopainen, A., L. Lepistö, R. Niinioja \& A. Rämö, 2008. Spatiotemporal and long-term variation in phytoplankton communities in the oligotrophic Lake Pyhäjärvi on the Finnish-Russian border. Hydrobiologia 599: 135-141.

IGEOE, Instituto Geográfico do Exército (Geografic Military Institute), 2006. Corine Land Cover 1990 and 2000. http://www.igeoe.pt/.

INAG, Instituto Nacional da Água (National Water Institute), 2006. Relatório intercalar do projecto "Qualidade ecológica e gestão integrada de albufeiras". (in Portuguese).

INE, Instituto Nacional de Estatística (National Statistics Institute), 2006. http://www.ine.pt.

Jonhson, R. K., M. Furse, D. Hering \& L. Sandin, 2007. Ecological relationships between stream communities and spatial scale: implications for designing catchment level monitoring programmes. Freshwater Biology 52: 939-958.

Lancaster, J. \& L. R. Belyea, 2006. Defining the limits to local density: alternative views of abundance-environment relationships. Freshwater Biology 51: 783-796.

Legendre, P. \& L. Legendre, 1998. Numerical Ecology, 2nd ed. Elsevier, New York.

Leira, M. \& S. Sabater, 2005. Diatoms assemblages distribution in catalan rivers, NE Spain, in relation to chemical and physiographical factors. Water Research 39: 73-82.

Li, J., A. Herlihy, W. Gerth, P. Kaufmann, S. Gregory, S. Urquhart \& D. P. Larsen, 2001. Variability in stream macroinvertebrates at multiple spatial scales. Freshwater Biology 46: 87-97.

Lim, D. S., J. P. Smol \& M. S. Douglas, 2007. Diatom assemblages and their relation ships to lakewater nitrogen levels and other limnological variables from 36 lakes and ponds on Banks Island, NWT Canadian Artic. Hydrobiologia 586(1): 191-211.

Liu, Q., 1997. Variation portioning by partial redundancy analysis (RDA). Environmetrics 8: 75-85.

Lund, J. W. G., C. Kipling \& E. D. Le Cren, 1958. The invertited microscope methods of estimating algal numbers and the statistical basis of estimation by counting. Hydrobiologia 11: 143-170.

Meót, A., P. Legendre \& D. Borcard, 1998. Partialling out the spatial component of ecological variation: questions and propositions in the linear modelling framework. Environmental and Ecological Statistics 5: 1-27.

Moss, B., S. Stephen, C. Alvarez, E. Becares, W. van de Bund, E. van Donk, E. de Eyto, T. Feldmann, C. FernándezAláez, M. Fernández-Aláez, R. J. M. Franken, F. GarcíaCriado, E. Gross, M. Gyllstrom, L.-A. Hansson, K. Irvine, A. Järvalt, J.-P. Jenssen, E. Jeppesen, T. Kairesalo, R. Kornijow, T. Krause, H. Künnap, A. Laas, L. Lill, H. Luup, M. A. Miracle, P. Nõges, T. Nõges, M. Nykannen,
O. Ott, E. T. H. M. Peeters, G. Phillips, S. Romo, J. Salujõe, M. Scheffer, K. Siewertsen, T. Tesch, H. Timm, L. Tuvikene, I. Tonno, K. Vakilainnen \& T. Virro, 2003. The determination of ecological quality in shallow lakes - a tested expert system (ECOFRAME) for implementation of the European Water Framework Directive. Aquatic Conservation: Marine and Freshwater Systems 13: 507-550.

Negro, A. I. \& C. De Hoyos, 2005. Relationships between diatoms and the environment in Spanish reservoirs. Limnetica 24: 133-144.

Økland, R. H. \& O. Eilertsen, 1994. Canonical correspondence analysis with variation partitioning: some comments and an application. Journal of Vegetation Science 5: 117-126.

Padisák, J., I. Grigorszky, G. Borics \& É. Soróczki-Pintér, 2006. Use of phytoplankton assemblages for monitoring ecological status of lakes within the Water Framework Directive: the assemblage index. Hydrobiologia 553: 1-14.

Padisák, J., L. O. Crossetti \& L. Naselli-Flores, 2009. Use and misuse in the application of the phytoplankton functional classification: a critical review with updates. Hydrobiologia 621(1): 1-19.

Pan, Y. D., A. T. Herlihy, P. R. Kaufmann, J. Wigington, J. van Sickle \& T. Moser, 2004. Linkages among land-use water quality, physical habitat and lotic diatom assemblages: a multi-spatial scale assessment. Hydrobiologia 515: 59-73.

Podani, J., 2000. Introduction to the Exploration of Multivariate Biological Data. Backhuys Publishers, Leiden.

Poff, N. L., 1997. Landscape filters and species traits: towards a mechanistic understanding and prediction in stream ecology. Journal of the North American Benthological Society 16: 391-409.

Reynolds, C. S. \& A. C. Petersen, 2000. The distribution of planktonic Cyanobacteria in Irish lakes in relation to their trophic states. Hydrobiologia 424: 91-99.

Reynolds, C. S., V. Huszar, C. Kruk, L. Naselli-Flores \& S. Melo, 2002. Towards a functional classification of the freshwater phytoplankton. Journal of Plankton Research 24: 417-428.

Rosenberg, D. M. \& V. H. Resh, 1993. Introduction to freshwater biomonitoring and benthic macroinvertebrates. In Rosenberg, D. M. \& V. H. Resh (eds), Freshwater Biomonitoring and Benthic Macroinvertebrates. Chapman and Hall, New York: 1-9.

Sabater, S. \& J. Nolla, 1991. Distributional patterns of phytoplankton in Spanish reservoirs. First results and comparison after fifteen years. Verhandlungen der internationale Vereinigung für Limnologie 24: 1371-1375.

Soininen, J., 2007. Environmental and spatial control of freshwater diatoms-a review. Diatom Research 22: 473490.

Snyder, C. D., J. A. Young, R. Villella \& D. P. Lemarie, 2003. Influences of upland and riparian land use patterns on stream biotic integrity. Landscape Ecology 18: 647-664.

Statzner, B., B. Bis, S. Dolédec \& P. Usseglio-Polatera, 2001. Perspectives for biomonitoring at large spatial scales: a unified measure for the functional composition of invertebrate communities in European running waters. Basic and Applied Ecology 2: 73-85.

Tavassi, M., S. S. Barinova, O. V. Anissimova, E. Nevo \& S. P. Wasser, 2004. Algal indicators of environment in the 
Nahal Yarqon basin, Central Israel. International Journal on Algae 6: 355-382.

ter Braak, C. J. F., 1986. Canonical correspondence analysis: a new eigenvector technique for multivariate direct gradient analysis. Ecology 67: 1167-1179.

ter Braak, C. J. F., 1987. Ordination. In Jongman, R. H. G., C. J. F. ter Braak \& O. F. R. van Tongeren (eds), Data Analysis in Community and Landscape Ecology. Pudoc, Wageningen: 91-173.

ter Braak, C. J. F. \& P. Šmilauer, 2002. CANOCO Reference Manual and User's Guide to Canoco for Windows Software for Canonical Community Ordination (Version 4.5). Microcomputer Power, Ithaca, NY: 352.

Tolotti, M., M. Manca, N. Angeli, G. Morabito, B. Thaler, E. Rott \& E. Stuchilk, 2006. Phytoplankton and zooplankton associations in set of Alpine high altidude lakes: geographic distribution and ecology. Hydrobiologia 562: 99-122.

Van Dam, H., A. Mertens \& J. Sinkeldam, 1994. A coded checklist and ecological indicator values of freshwater diatoms from the Nederlands. Nederlands Journal Aquatic Ecology 28(1): 117-133.

Van den Brink, P. J. \& B. J. Kater, 2006. Chemichal and biological evaluation of sediments from the Wadden Sea, The Netherlands. Ecotoxicology 15: 451-460.

Van den Brink, P. J., J. Hattink, F. Bransen, E. Van Donk \& T. Brock, 2000. Impact of the fungicide carbendazim in freshwater microcosms. II. Zooplankton, primary producers and final conclusions. Aquatic Toxicology 48: 251-264.

Vasconcelos, V. M., 2001. Toxic freshwater cyanobacteria and their toxins in Portugal. In Chorus, I. (ed.), CyanotoxinsOccurrence, Effects, Controlling Factors. Springer Publishers, Heidelberg: 64-69.

Venrick, E. L., 1978. How many cells to count? In Sournia, A. (ed.), Phytoplankton Manual. UNESCO: 167-180.

Wiley, M. J., S. L. Kohler \& P. W. Seelbach, 1997. Reconciling landscape and local views of aquatic communities: lessons from Michigan trout streams. Freshwater Biology 37: 133-148. 